\title{
Resimli ve Temsili Bir Triyalektik Mekân Okuması Olarak Ekümenopolis
}

\author{
Yrd. Doç. Dr. Hakan ERKILIÇ \\ Doç. Dr. Ulaş BAYRAKTAR
}

mersin üniversitesi iletişim fakültesi radyo televizyon sinema bölümü erkilichakan@gmail.com mersin üniversitesi iibf kamu yönetimi bölümü ulasbayraktar@gmail.com

\section{Abstract \\ "Ekümenopolis" as an Illustrated and Representative Trialectic Reading of Space}

Constantinos A. Doxiadis's notion of Ecumenopolis implies the enlargement of cities to such an extent that they become a single city without borders. Imre Azem's movie with the same title presents this theoretical framework, the transformation of the city to an important area of capitalist attraction as a result of contemporary neoliberal policies, through the structural changes in Istanbul. The movie highlights the experience of right to the city based resistance of the victims of urban transformation. It is possible to see the Ecumenopolis as the illustration of the zeitgeist of the pre-Gezi period and in a sense foreshadowing the Gezi protests.

In the framework of this paper, we will undertake such a reading in the light of Henri Lefebvre's trialectic spatial analysis. The movie will be thus examined through three different dimensions based on how cities are interpreted, designed and experienced; in Lefebvre's terminology through spatial practices, representation of space and space of representation.

keywords: Ekümenopolis, Henri Lefebvre, production of space, visual sociology, documentary films 


\section{Résumé}

\section{"Ekümenopolis" en tant qu'une lecture illustrée et représentative de l'espace}

La notion "Ecumenopolis" de Constantinos A. Doxiadis implique l'élargissement des villes, à tel point qu'elles deviennent une ville unique sans frontières. Le film de Imre Azem portant le même titre présente ce cadre théorique, cette transformation de la ville à une importante zone d'attraction capitaliste en tant qu'un résultat des politiques néolibérales contemporaines, à travers les changements structurels à Istanbul. Le film souligne l'expérience de résistance des victimes de la transformation urbaine, basée sur le concept de droit à la ville. Il est possible de voir l'Ecumenopolis comme une illustration de "zeitgeist" de la période pré-Gezi préfigurant les protestations de Gezi.

Dans le cadre de cet article, nous allons entreprendre une lecture à la lumière de l'analyse spatiale trialectique de Henri Lefebvre. Le film sera donc examiné à travers trois dimensions différentes qui conforment à la terminologie de Lefebvre (des pratiques spatiales, la représentation de l'espace et l'espace de la représentation) à propos de la façon dont les villes sont interprétées, conçues et expérimentées.

mots-clés : Ekümenopolis, Henri Lefebvre, production de l'espace, sociologie visuelle, films documentaires

\section{Özet}

Constantinos A. Doxiadis'in Ekümenopolis kavramı, şehirlerin büyüyerek tek bir şehir olacağı tahayyülü üzerine odaklanır. Imre Azem'in aynı adlı filmi de bu teorik çerçeveyi, günümüzün neoliberal politikaları sonucu sermayenin önemli bir çekim alanına dönüştürülen kenti, Isstanbul'daki yapısal değişimler üzerinden öyküler. Film, kentsel dönüşüm mağdurlarının kent hakkı bağlamında oluşturdukları direnme deneyimin altını çizer. Ekümenopolis'i, Gezi öncesi dönemin ruhunu yakalayabilen ve bir anlamda Gezi'yi öncülleyen film olarak okumak mümkündür.

Bizler bu metin çerçevesinde böylesi bir okumayı Henri Lefebvre'nin triyalektik mekân analizinin ışığında gerçekleştireceğiz. Filmi, Lefebvre'in kentlerin nasıl anlamlandırıldığı, tasarlandığı ve deneyimlendiği konusunda geliştirdiği ve mekânsal pratik, mekânın temsili ve temsilin mekânından oluşan üçlü yaklaşım bağlamında inceleyeceğiz.

anahtar kelimeler: Ekümenopolis, Henri Lefebvre, mekanın üretimi, görsel sosyoloji, belgesel sinema 
Temsil etme, aktif bir seçme ve sunma, yapılandırma ve biçimlendirme işini ima eder: Yalnızca zaten var olanı anlamı aktarma değil; ama daha aktif bir şeylere anlam verme işini ima eder. Söz konusu olan bir anlam pratiğidir, anlam üretimidir (Hall 1994: 88).

Dünyanın temsili dönüştürüldüğünde dünyanın da dönüştürülebileceğini kabul etmek gerekir (Bourdieu, 2010: 88)

\section{Giriş}

Son zamanlarda kente yönelik yoğun bir ilgi gözlüyoruz. Başlı başına bir metaya dönüşmenin yanı sıra, bağlantılı bir çok rant üretim ve bölüşüm mekanizmasını bünyesinde barındırması kente dair ekonomik ilginin artıyor olmasını anlaşılır kıııyor. Bu artan ekonomik ilgi karşılığını sosyal bilimlerin çeşitli alanlarında da buluyor. Siyaset bilimi, sosyoloji, tarih, iktisat gibi temel disiplinler içinde kent çözümlemelerinin sayısı son zamanlarda müthiş bir artış sergiliyor ${ }^{1}$.

Bu artan kent araştırmalarının dikkate değer bir diğer yönü bu çalışmalarda gitgide daha fazla görsel malzemeye yer veriliyor olması. Dijital teknolojilerin görsel veri üretme konusunda sunduğu olağanüstü olanaklarla yakın zaman değin ağdalı dilleri, teknik terminolojileri, akademik kavramları ile sadece uzmanlara hitap eden akademik çalışmalar, görsel anlatım ya da bulgular sayesinde çok daha geniş kitlelere ulaşma şansına kavuştu. Bu eğilimin en kristalize olmuş hali, kente dair belge filmlerin ve belgesellerin sayısının hızla artması ${ }^{2}$. Akademinin kentsel çalışmalarda görsel malzemelere başvurma eğilimi, sanatçıların da kentin bilimsel ve politik yönlerini yorumladıkları eserlerde karşılık buluyor. Artan kent çalışmaları ve yaygınlaşan görsel içerik kullanımı bu çalışmanın da iki ana tartışma eksenini oluşturuyor.

Bu metin çerçevesinde, popülerleşen kent çalışmalarının son zamanlarda en dikkate değer görsel örneği olan Ekümenopolis: Ucu Olmayan Şehir (2011) belgeselini ele alıyoruz. İstanbul'un kentsel dönüşümünün ekonomi politik serüvenini kâh uzmanların, kâh bu sürecin fail ve mağdurlarının ağzından aktaran Imre Azem'in belgesel filmini iki farklı açıdan ele alacağız. Film öncelikle bir görsel sosyoloji yapıtı olarak ele alınacak. Bu amaçla, sosyal bilimlerin görsel öğe ve araştırma yöntemlerine artan ilgisine dair bir literatür taraması gerçekleştireceğiz. Özellikle Ulus Baker'in duygular sosyolojisine odaklanacak bu tartışma son yıllarda sayıları artan Türkiye belgeselleri üzerinden Ekümenopolis'e uzayacak şekilde ilerleyecek.

Ikinci inceleme eksenimiz belgeselin tekabül ettiği metodolojik kategorinin ötesinde içerdiği tartışmaya odaklanacak. Bu anlamda Ekümenopolis'i İstan-

1 Bu artan ilgiye dair birkaç örnek için bkz. Lefebvre (2011;2013;2014), Smith ve Williams (2015), Kars Kaynar (2015), Koca vd. (2014), Brenner vd. (2014), Türkün (2014), Özbay ve Candan (2014), Akşeker ve v.d. (2013).

2 Gezi olaylarına dair gerçekleştirilen belgesellere dair bir tartışma bkz. (Bayraktar \& Erkılıç 2014) 
bul'un kentleşme dinamiklerine dair önemli veriler içeren bir belge olarak ele alacağız. Filmde yer verilen kişiler, görüşler ve görüntüleri konuya dair yapılan bir alan çalışmasının adeta görgül bulguları olarak kabul edeceğiz. Bu verileri de Lefebvre'nin triyalektik mekân yaklaşımının filtresinden geçirip, analitik bir düzleme taşıyacağız. Lefebvre'in kentlerin nasıl algılandığı, tasarlandığı ve deneyimlendiği konusunda geliştirdiği ve mekânsal pratik, mekânın temsili ve temsilin mekânından oluşan üçlü yaklaşımı bizim de Ekümenopolis'i tartışırken izleyeceğimiz temel referans olacak. Bu anlamda metin bir metodolojik değerlendirmenin ötesinde, kuramsal bir tartışma da içerecek. Fakat filmi yazarın triyalektik yaklaşımı ışığında ele alma tercihimizin detaylı bir Lefebvre tartışması gerektirmediğine inanarak metinde sadece bu kavramsal çerçeveye yer vereceğiz. Dolayısıyla, çalışmamızın Lefebvre hakkında değil, onun triyalektik bakışı kullanan bir metin olduğunu özellikle vurgulamalıyız.

Inceleyeceğimizi filmin görselliğini, kuramsal bir tartışmanın ampirik zemini olarak kullanmanın çok da konvansiyonel bir yöntem olmadığı aşikar. Fakat bu seçim tam da Ulus Baker'in duygular sosyolojisi olarak adlandırdığı alanda bir örnek egzersiz sayılabilir çünkü filmi tartışmaya geçtiğimizde tekrar ifade edeceğimiz gibi film sadece sözü, ifadeyi içermenin ötesinde yazıyla ifade edilemeyecek duyguları da aktarma ayrıcalığına sahip bir görgül kaynak teşkil ediyor. Bu anlamda metinde üç farklı yönteme başvurmuş olacağız. Bir yanıyla görsel sosyoloji yazınına dair bir literatür ve örnekleme çalışması yapacağız. Bununla birlikte Lefebvre üzerinden kuramsal bir mekân ve kentleşme tartışmasına analitik çerçeve olarak başvuracağız ve bunu yaparken de filme vereceğimiz referanslarla duygular sosyolojisine dair bir tartışma açmaya yelteneceğiz.

\section{Sosyal Bilimler Alanında Belgeselin Yeri ve Önemi Üzerine}

Girişte de ifade etmiş olduğumuz gibi, sosyal bilimlerin, klasik araştırma tekniklerinin (anket, istatistiki veri, diyagramlar vb.) yanı sıra gitgide daha yoğun olarak görsel materyallere başvurmakta olduğunu gözlüyoruz. Bu yönelimi daha iyi anlayabilmek için bu bölümde önce görsel sosyoloji yaklaşımını, daha sonra da Ulus Baker'in sosyal bilimler ile belgeseli birleştirme çabasını ele alacağız.

Sosyal bilimlerin klasik yöntemlerinin yanında "imge, sosyal bilimler alanını keşfediyor ve yeni bir araştırma yöntemini ortaya çıkarıyor: görsel sosyoloji" (La Rocca 2012: 69). Sosyal bilimlerde tarihsel süreci ve toplumsal gerçekliği tanımlamak için fotoğraf, film ve video kullanılmaya başlanıyor. Harper'ın (1988: 55) ifadesi ile Avrupa'da aynı yıllarda doğmuş olan bu iki alandan fotoğraf görmeye, sosyoloji de yorumlamaya yeni bir yol açmıştır. Özellikle antropoloji çalışmalarında "görsel düşünme" başlığı altında bu türden çalışmalara başlanıyor ve diğer disiplinlere yayılıyor ${ }^{3}$. Görsel sosyolojinin amacı "fotoğraf, video ve filmi

3 Bu alandaki ilk çalışmalar Margaret Mead ve Gregory Bateson araştırma projesidir ve onların Bali Karakter (1942) fotoğraf analiz için bir model olmaya devam etmektedir (Harper 1988: 58). 
toplumu anlamak için kullanmaktır" ve bu bağlamda görsel sosyoloji yapmak "sosyolojik bilinçle film ya da fotoğraf çekmek" demektir ${ }^{4}(70)$. Çünkü fotoğraf ve video daha kolay veri sağlamanın bir yolu olarak değerlendiriliyor. Fotoğraf, anın kaydını sabitlerken birçok yazı ve ifadeden daha fazla gerçekliğe dair enformasyon taşır. Görsel sosyoloji, portre fotoğrafçılığından sonra belgesel fotoğrafçılıkla da ilişki içinde olur. Video ve filmin görsel-işitsel boyutu verili koşullar altında insan ve çevresine ilişkin gerçekliği, duyguları, davranış biçimlerini kaydedip, yeniden üretirler. Görsel anlatım, tanımlama, bağlamların araştıııması ve yorumlanması açısından sosyolojik süreçleri daha iyi anlamak için fırsatlar sunuyor. Böylece sosyal bilimlerde bilgi aktarımında ve üretiminde hâkim olan kelimeler, sayılar, grafikler, tabloların yanına görsel-işitsel öğeler yer almaya başlıyor.

Bu çerçevede iki temel yol benimseniyor: Birincisi, saha araştırmasını fotoğraf çekerek belgelemek ve bu görsel deneyim üzerinden yorumlamak. íkincisi ise daha önce çekilmiş görsel materyallerin yorumlanması yoluna gitmek ${ }^{5}$ (Harper 1988: 55). Bu bağlamda sosyoloji, 1960'dan günümüze görsel teknikleri kullanarak araştırma yöntemlerini çeşitlendirmiş sayılabilir. Bu bağlamda belgesel sinema, sosyal araştırmalar içinde görsel bir metot olarak kendine yer bulur (Banks 2010). Bir çok toplum, kültürel ve davranış bilimci gençlik kültüründen göç hareketlerine, aile incelemelerinden travma deneyimlerine, ırk ve etnik üzerine çalışmalardan toplumsal cinsiyet ve kimliğe, doğa kültür karşıtığından küreselleşmeye kadar farklı konu ve kavram bağlamında belgeselden yararlanarak görsel sosyoloji bağlamında çalışmalar yürütürler6 ( Pauwels 2010: 551).

Ulus Baker aynı zamanda doktora tezi de olan Kanaatlerden imajlara Duygular Sosyolojisine Doğruadlı çalışmasında, Spinoza ve Simmel'den hareketle "duygular sosyolojisi"nde sosyal bilimler alanı ile özellikle de belgesel sinemayı birleştirmeyi önerir. Sosyal bilimlerin toplumsal tip yaratmada sıkıntılar yaşadığına dikkat çekerek kanaate dayalı yaklaşımın yerleştiğini vurgular ve sanat alanı ile de araştırma yapılabileceğini ileri sürer: " ... görsel, sesli, metni göstergeler olarak içeren 'arşiv' tarzında bir sosyolojik sunuşu önerecek ve sinematografiye içkin olduğuna, temsil edişin metinsel biçimde ise bulunmadığına inandığımız 'montaj düşünce'yi sosyoloji ile - 'işbirliği' veya illüstrasyon desteği'nden ibaret olmayanbelgesel filmin birleşik alanı içinde geliştirmeyi hedefleyeceğiz (2010: 29). Baker, kanaatler sosyolojisinin görsel olana yönelik kuşkulu yaklaşımının farkındadır: "Kanaatler sosyolojisi genel olarak 'görsel'e güven duymaz, onu 'metne' ve 'yorumlamaya' tabi kılmaya zorlar ve fotoğrafın icadından beri modernite ile eş

4 Bu amaçla örgütlenme çalışmalarına da başlanılmış ve Uluslararası Görsel Sosyoloji Birliği (IVSA) kurulmuştur.

5 Bu çerçevede görsel yöntem, imgeler hakkında sosyoloji ve sonuçlarının düzenlemesinden oluşur ve foto değerlendirme, anlatımsal imge üretimi, sahada fotoğrafik araştırma, etkileşimin video kaydının alınması tekniklerini içerir (La Rocca 2012: 70-71)

6 Ayrıca yeni medyanın gelişimi ve örneğin toplumsal hareketlerde akıllı telefon kayıtların kullanımı ve görüntülerin video sunucu sitelerinde paylaşılıyor olması görsel sosyoloji alanında yeni fırsatlar açmaktadır. 
süreli olan devasa 'imajlar' dünyasının çalışabilmeye muktedir tek çözümleyici otorite olduğunu varsayar"(26).

Baker'in belgesel filme yaklaşımı, görsel sosyolojinin fotoğraf, film ve videoyu destekleyici bir unsur olarak gören yaklaşımından ayrılır; gündelik hayatı anlamanın ve anlamlı kılmanın bir yolu olarak görür. "Sadece, 'duygular' ile onları somut yaşam koşulları içinde görselleştirebilme ihtimali arasında güçlü bağlar olduğunu iddia ediyoruz. Bu nedenle sırf örnekleyici 'görsel sosyoloji'nin ötesine geçerek 'belgesel olarak adlandıracağımı alana ulaşma iddiasında bulunacağız" (26). Sosyal bilimlerin toplumsal tipler yaratarak çözümlemeler yaptığına dikkat çeken Baker (101-103), günümüzde sinemanın başlangıç yıllarından itibaren hem toplumsal tipler yarattığını hem de gündelik hayatın imajlarını kaydederek belge işlevi üstlendiğini belirtir:

\begin{abstract}
"'Sinematografik' imajın doğuşu gündelik yaşamın içindeki toplumsal tiplerin yeniden üretilmesinde çok daha fazla etkili olmuştur. Ekili bir iletişim aracı olarak sinema, tıpkı fotoğrafçılık gibi, 'kendinde-belge' olma işlevini derhal üstlenir. Ama hareketsiz bir düzeneğe dayandığından gerçek yaşama olan uzaklığı apaçık olan fotoğrafçılıktan fazla olarak, sinematografi sinematik göstergelerin 'iz' özelliğini çoğaltır ve onlara 'hareket yanılsaması' kazandııır... Ve bir toplumsal tipler galerisi... değil, ama aynı zamanda sokak hayatının sıradanlığının temsil edilişinde de sinematografide hep mevcuttu" (99).
\end{abstract}

Baker'in sinema ve video yaklaşımı Vertov'un sine-göz ve sine- gerçek kuramına ve Godard'ın videoyu düşünme cihazı olarak gören yaklaşımından beslenir:

\begin{abstract}
"Belgesel, toplum bilimlerin kendine ait, metinsel ve akademikleşmiş alanında geliştirebildiği şeyin ihtiyacı içinde. Bu yüzden toplumsal bilimler ile 'imajların', görsel-işitsel tekniklerin ve 'belge-imaj'ın kudretlerinin taşıdığı olanaklar arasında bir birleşmeyi önermeye mecbur kalmıştık... Sinema ve video günümüzde görünmeyeni görülebilir kılmaya, 'fikirler' oluşturmak için seçilmiş ve monte edilmiş bir ilişkiler demeti yaratmaya yöneltilmiştir" (345).
\end{abstract}

Baker (2002), sosyal bilimci ile belgeselcinin bir olay sırasındaki farkını betimlerken sosyal bilimler alanına belgesel filmin katkısını "görmek" ve "hissetmek" bağlamında açık bir şekilde belirtir.

"... Derdim sosyal bilimlerde eksik olan bir şeyi "belgesel" denen ama bence filmik yaşantıların toplamına yayılması gereken bir uğraşıyla bütünlemek, entegre etmekti... Ne belgeselciyim ne de video sanatçısı. Sonuçta bir "görsel-işitsel arşiv" sıkıntısı çeken bir sosyal bilimci diyebilirsiniz bana. Ama diğer sosyal bilimciler gibi videografik kaydın ve arşivin salt bir illüstrasyondan ibaret olamayacağını hissediyorum. Mesela "yoksulluk" üstüne bir araştırmada çevrede, odanın içinde gezdirilen bir kameranın bir anketin metinsel kayıtlarından çok daha "bilgi verici", yani "duygulandırıı" olabileceğini biliyorum. Belgesel sinemacılar sosyal bilimcilerden çok daha güçlü etik kaygılara sahipler (gazetecileri bir tarafa bırakırsak). Çünkü kullandıkları ortamın insanlar üstündeki etkisinin ne kadar büyük olduğunu hissediyorlar. Böyle bir kaygıyı ben hiçbir 
sosyal bilimcide görmedim. Biz anketimizi yaparız, geçeriz... Sonuçlarımızı çıkarııı büyük bir rahatlıkla... Ama bu araştırdığımız yoksulluğu "gördüğümüz" manasına gelmez. Onu belki "anlarız", "söyleriz", "iletiriz" ama "görmeyiz". Oysa yoksulluğun pekâlâ birçok, belki de sonsuz imajı vardır... Bu noktada sanat ile bilim arasında herhangi bir klasik ayrıma başvurmam gerekmez. Sanat eserinde "düşünülmediği" gibi bir varsayım imkânsız olduğuna göre, düşünürken aynı zamanda hissedilmediği gibi bir fikir de sonsuzca anlamsız görünüyor bana."

Baker'in üzerinde durduğu önemli nokta, imgenin her zaman duygu ya da etkilenim doğuran bir şey olduğu ve günümüzde hiçbir toplumsal olayın imgelere kaydedilmeden var olamadığı gerçeğidir. "Burada 'duygulandırıcı olmaktan' kasıt olguyu olay üzerinden görme, anlama ve içselleştirmeyle ilgilidir. Kayıt altına alınmış bir şimdi, kuru anket bilgilerini aşan bir hayatı yansıtabilir" (Susam 2015: 164). Belgesel sinema, bilimsel ve estetik olanın gidimli ilişkisi sonucunda oluşur. Böylece belgesel sinemanın kanaatler sosyolojisine karşı yaratıcı bir gözlemi ön plana çıkarttığı ileri sürülebilir. Bu tutumun sosyal bilimcinin metinsel düşünceden görsel düşünceye doğru yönelmesini sağlar. Susam " 'duyguların imajlarını oluşturmak' belgesel sinemada nasıl bir karşılaşma olabilir?" diye sorar ve şöyle açıklar: " Eylerken düşünce üreten belgeselci tanıklık ederken faillik de eder aynı zamanda. Hem gözleyen hem de katılan olarak hem çekerken hem de kurarken müdahalecidir. Bu müdahalelerle duyguların ve anlamların imajlar aracılığıyla yeniden üretimini sağlayabilir" (166). Ocak'ta (2008: 239) benzer bir şekilde belgeselci bir tavırla çekilen görüntülerin enformasyonun yanı sıra duygular açığa çıkaracağı ve bu durumun bizatihi başka bir araştırma yöntemi olabileceğini belirtir.

Ekümenopolis: Ucu Olmayan Şehir(İmre Azem, 2011), kentsel dönüşümü, kenti rant olarak gören günümüz sistemini ve buna karşı koyan kentsel muhalefeti röportaj tekniği ve animasyonlarla perdeye taşıyor ${ }^{7}$. Neoliberalizm uygulamaları ve kentsel dönüşüm süreci sonucu bir taraftan özel güvenlikle sitelerine, aynı

7 Bu bağlamda Ekümenopolis: Ucu Olmayan Şehir (2011) belgesel filminin çözümlemesine geçmeden önce sinema ve özellikle de belgesel sinemanın toplumsal sorunlarla olan ilişkisine kısaca değinmek yararlı olacaktır. Yeni Türkiye Belgeselleri olarak da nitelen son yılların belgesel filmleri, bir anlamda gerçekle yüzleşme (Yeni Bir Yurt Edinmek, Enis Rıza, 2001; Ayrıı̆ı̆ın Yurdu Hüzün: Kayaköy, Enis Rıza 2006 gibi), resmi tarihi sorgulama (Mustafa, Can Dündar, 2008; Sessiz Ölüm, Hüseyin Karabey 2001; 5 Nolu Cezaevi, Çayan Demirel 2009; Oğlunuz Erdal, Tunç Erenkuş 2010; iki Tutam Saç Dersim'in Kayıp Kızları, Nezahat Gündoğan'ın 2010 gibi), kadın ve toplumsal cinsiyet (Benim Çocuğum, Can Candan, 2012; Pippa'ya Mektubum, Bingöl Elmas 2010; Ölüm Elbisesi: Kumalık, Mizgin Müjde Arslan 2009 gibi), kültür (Son Mevsim: Şavaklar, Kazım Öz 2008; Anadolu'nun Son Göçerleri: Sarıkeçililer, Yüksel Aksu 2010 gibi), kent (Yer Yüzü Așkın Yüzü Oluncaya Dek, Reyan Tüvi, 2014 ve diğer gezi belgeselleri; Validebağ Direnişi, Hakan Tosun, 2014 gibi) ve çevre (Son Kumsal Rüya Arzu Köksal ve Aydın Kudu 2008; Kanımızı Veririz Suyumuzu Vermeyiz, Bilen 2010; Hayat Var! Yırca, Kâzım Kızıl, 2014; Akıntıya Karșı, Kocagöz ve Işıl 2012, Bir Avuç Cesur Insan, Rüya Arzu Köksal, 2013 gibi) gibi sorunlar karşında mücadele ve ifade alanı olarak belgeseli konumlandıırken pek çok toplumsal ve siyasal olayı perdeye taşır, geçmişle hesaplaşmayı sağlar ve toplumsal bellek işlevi görmeye başlarlar. Ele alınan konu, tarz ve tema farkılıklarına karşın bu filmler, belgesel sinemayı bir mücadele ve ifade aracı olarak görür ve ele aldığı sorunları derinlemesine işleyerek toplumda farkındalık yaratırlar. 
zamanda TOKi konutları bağlamında yeni yoksulluk alanlarına ve ekolojik dengesi gün geçtikçe bozulan İstanbul'daki değişim, alanın uzmanlarının bilimsel yaklaşımları ve yerinden edilen mahalle sakinleri olarak konunun mağdurlarının oluşturduğu sosyal aktörlerin tanıklıkları üzerinden aktarılmaktadır. Film, kentin morfolojisi ve sosyolojisini bozan siyaset ile kentsel dönüşüm mağdurlarının kent hakkı bağlamında oluşturdukları direnme deneyiminin altını çizer. Yönetmen Imre Azem'in İstanbul üzerine film yapma düşüncesi, bir yetkilinin radyoda dinlediği 3. Köprü yapımı üzerine açıklamaları ile yoğunlaşmaya başlar. Ancak araştırma sahasında durumun 3.köprüyü de aşan büyük bir İstanbul vizyonu ile karşı karşıya kaldığını görür ve kente bütüncül olarak bakmaya karar verir (Aytaç, vd. 2012). Film altı bölümden oluşur: Küresel Kent; Sistemin Dinamikleri; 3. Köprü Meselesi; (Anti)Sosyal Konut Modeli; Plan, Sermaye, Demokrasi; Mahalle. Film, Constantinos A. Doxiadis 1968 tarihli Ekümenopolis: Yarının Şehri adlı makalesinden hareketle büyüyen ve diğer şehirlerle birleşerek bir megapole dönüşen İstanbul'u anlatır. Doxiadis, 150 yıl sonra (nüfus ve ekonomiye bakarak) bütün şehirlerin büyüyerek tek bir şehir (megapolis) haline gelecek öngörüsünü geliştirir. Makalede temel olarak iki yaklaşım vardır. Distopya, iyi inşa edilmeyen, insani boyutlara önem vermeyen, otobanların, arabaların ve kirliliğindeki şehirler, insanlığın sonunu getirecektir. Ütopya ise kent iyi inşa edilirse, (ulaşım yerin altından, toprağın üstü de yaşam alanları olarak kullanılacak) insanlık din, dil, köken ayrımı olmaksızın kentsel hizmetlerden, sanat ve kültür olanaklarından yararlanacaklardır. Ekümenopolis karamsar, neredeyse distopik bir belgesele dönüşür. Fakat filmin bu karamsarlığın ötesinde bir analitik çerçeveye sahip olduğu, onu, konu ettiği sorunlar bağlamında çok sık referans verilen Henri Lefebvre'in gözüyle izlediğimizde anlaşılabilecektir.

\section{Lefebvre'in Triyalektik Yaklaşımı}

Giriş bölümünde de belirttiğimiz gibi, son zamanlarda sayıları gittikçe artan kent çalışmaları içinde özellikle kentsel toplumsal direniş, eylem ve hareketleri bir kent hakkı olarak ele alma eğiliminin ilk düşünürü Henri Levebfre ile onun günümüzdeki en bilindik yorumcusu olarak David Harvey (2008) kent kuramcıları arasında öne çıkıyor. Kent hakkı bir yandan barınma, hijyen, sosyal ve kültürel hizmetler ile sağlık ve eğitim gibi temel insani ihtiyaçlara, öte yandan da kent yönetimlerinde söz sahibi olmaya yönelik bir hak talebi ve örgütlenme dinamiği olarak tasavvur ediliyor. Lefebvre'in bu kavramı kullanışının 1968 yılına denk gelmesi haliyle o dönemin yoğun toplumsal hareketliliğinden ayrı düşünülemez. Nitekim Lefebvre de bu hareketliliğin kökeninde hayat tarzlarını tektipleştirme eğilimi sergileyen ve gündelik hayatın düzenlenip sömürgeleşmesine dayanan "kent krizi" görüyordu (Schmid 2014: 72):

"Gençlerin, öğrencilerin, entelektüellerin, beyaz yakalı olan ya da olmayan işçi ordularının, taşradan gelen insanların, her türlü sömürgeleştirilmiş ya da yarısömürgüleştirilmiş insanların şartlarını; çok iyi düzenlenmiş gündelik hayatlara katlanmak zorunda kalan herkesin durumunu uzun uzun anlatmak gerekli midir? Burada, kent sakininin önemsiz ve gülünç perişanlığını, banliyölerde 
yaşayan, gettolarda kalan, eski şehirlerin çürüyen merkezlerinde ve bu şehirlerin merkezlerinden uzak tümörlerinde oturanları sergilemek gerekli midir? Evinin yakınında ya da uzağında bulunan istasyona, ağzına kadar dolu metroya, ofise ya da fabrikaya koşan ve akşam, aynı yoldan evine bir sonraki gün için yeniden güç toplamaya dönenlerin gündelik hayatlarını anlayabilmek adına gözlerimizi açmamız yeterlidir. Bu genelleşmiş perişanlık tablosu, onu gizleyen, akla gelmesini engelleyen ve ondan kurtulmak için kullanılan "memnuniyet" tablosu olmadan yürüyemeyecektir." (Lefebvre 2011 [1972], 152).

Kent hakkını böylesi bir kent krizi olarak tarif etmesinden üç ay sonra Mayıs 1968'de yaşanan toplumsal eylemler ışığında Lefebvre (2013) bu yaklaşımı gözden geçirip, genişleterek iki yıl sonra Kentsel Devrim başlığıyla yayınladı. Burada kent artık "şehir" ve "kırsal" gibi kategorilerle sınırlandırılamaz. Kentin "belirgin bir şekilde kentli olan bir yaşam tarzına ortam hazırlayan, sınırları kesin olarak çizilebilir bir birim olduğu varsayımı" (Schmid 2014: 77) yazara göre artık geçersizdir. Marx'ın tarihsel materyalizme dayanarak kenti bir süreç ve bir toplumsal mekân olarak tasavvur etmeye soyunur (Costes 2010: 179). Böylece kent bir süreç olarak analiz edilebilir hale gelir. Bu sürecin en temel dinamiği de Lefebvre'in sadece coğrafi ve fiziki değil, toplumsal ve siyasal anlam ve işlevleri olan bir olgu olarak gördügü mekân üretimidir.

Bu bakış, insanların mekânlarla kurdukları ilişkilerin iktidarla olan bağını analiz etmekle mümkün olabilmiştir. Nitekim mekânı toplumsal bir ürün olarak görmek, bu toplumsallığın kökenindeki üretim ve yeniden üretim ilişkilerini analiz edebilmemize de izin verir (Lefebvre 2014: 62).

Lefebvre mekânın üretimini üç farklı sürecin sonucu olarak yorumlar. İlk olarak mekânsal pratikler, gündelik yaşamın mekân üzerindeki tezahürü, bu yaşam edimlerinin kendine katılmasıdır. Serpilip gelişme, karşılıklı konuşma, yasaklarla karşılaşma ve ölüm bu mekânda gerçekleşir. Düşüncelerin edimsellik kazanması yani gerçekleşmesi ancak mekân içinde ve mekân dolayısıyla olabilir. Nitekim "insan sadece kelimelerle yaşamaz; her 'özne' kendini tanıdığı ya da yitirdiği, dolayısıyla yararlandığı ya da değiştirdiği mekânın içine yerleşir" (64). Pratikler üzerinden gerçekleşen bu yerleşme nihayetinde kendi mekânını yaratır. Bu yüzdendir ki, mekânsal pratiğin keşfi ancak mekânın deşifre edilmesi ile mümkündür (67). Edimler kadar yasaklar da mekânda cismanileşen toplumsal pratikler arasında sayılır çünkü duvar, çit, fasad gibi fiziki engeller, sahne kadar, sahne dışını yani müstehceni işaret eder, toplumsal bilinçdışına dair ipuçları barındııı (65-66).

Mekânsal pratikler üzerinden böylece algılanan mekân belli bir aklın ve yönetimin tasarruflarının etkisinde olduğu sürece aslında bir tasarıdır da aynı zamanda. Lefevbre'in mekânın temsili olarak terimleştirdiği bu tasarlanmış mekân "bilginlerin, planlamacıların, şehircilerin, 'parçalayan' ve 'düzenleyen' teknokratların, yaşamı ve algılananı... Tasarlananla özdeşleştiren, bilimselliğe yakın kimi sanatçıların mekânı" olarak tarif edilir (68). Bu temsil üretim ve 
yeniden-üretiminin sürekliliğini mümkün kılan mekânsal bağlılıkla ortaya çıkar. Bu bağlılık hem bir yeterlilik hem de bir performans gerektirir. Iktidarın, karar verici ya da politika yapıcıların mekânı nasıl tahayyül ettikleri mekânın siyasi ve bilimsel olarak nasıl temsil edildiğine ışık tutar. Dolayısıyla mekânın temsili, mekânın düzen, bilgi, kodlar ve cephesel ilişkilerle algılanması ve kurgulanmasına işaret eder. Bu anlamda da ideoloji ve bilginin bir karışımından müteşekkildir.

Bu siyasi ve/veya teorik temsil çoğu zaman söz konusu mekânın asıl kullanıcılarının mekânı nasıl tecrübe ettiklerine, yaşadıklarına tekabül etmez. Kullanım değerini ve şeklini öne çıkaran temsil mekânları yani oturanların, kullananların mekânları "toplumsal yaşamın yasadışı ve yeraltı tarafına bağlı" olarak mekânsal üretimin karmaşık sembolizmlerinden oluşan üçüncü ayağını ortaya koyar (s. 63). Bir tasarıdan çok yaşama dair olan bu mekânlar "ne tutarlıığa, ne de bağlantıya mecburdur" (70) çünkü kökenleri tarihtir ve dolayısıyla zamansallık ana niteliklerindendir: "Temsil mekânı yaşanır, konuşur; duyumsal bir çekirdeği ya da merkezi vardır: Ego, yatak, oda, konut ya da ev; meydan, kilise, mezarlık... Bu mekânlar, tutku ve eylem yerlerini kapsar, dolayısıyla zamanı doğrudan içerir." (71).

Gülhan'ın (2013: 43) somutun, zihnin ve yaşamın mekânı olarak tarif ettiği bu mekânın üretim süreci böylece Lefebvre tarafından kendi içlerinde diyalektik bir ilişkiye sahip üç momentli bir toplumsal mekân biçiminde triyalektik bir perspektifte tarif edilir. Lefebvre algılanan, tasarlanan ve yaşanan arasındaki bu diyalektik ilişkiyi bedene, vücuda gönderme yaparak açar. Öncelikle mekânsal pratikle kastedilen bedenin "ellerin, uzuvların, duyumsal organların, çalışma hareketlerinin ve çalışma dışı faaliyet hareketlerinin" (Lefebvre 2014: 69) kullanımına benzer. Algılanabilmesi için bir bedene ve bu bedenin hareketlerine intiyaç vardır. Pratiklerle algılanabilir hale gelse de, her beden herkesçe aynı şekilde görünmez, çünkü bedenin temsili "ideolojiyle karışarak yayılan bilimsel" bir kazanımın eseridir. Bilişsel bir tasarım olarak düşünülebilecek bu temsil algılanın belli bir açıdan idrak edilmesini sağlayan üretim süreci sayılabilir. Somut olarak algılanan, bilişsel olarak idrak edilen bu beden neticede yaşayan bir bedendir. Yunus Emre'nin "bir ben vardır benden içeri" mısralarını hatırlatan bu yaşayan beden; düşünen, hisseden, arzulayan, acı çeken bir duygusal varlık olarak karşımıza çıkar.

Lefebvre'den ödünç aldığımız bu triyalektik okumayı Ekümenopolis filmine uyguladığımızda karşımıza mekânsal pratik olarak inşa faaliyetleri, mekânın temsili olarak dünya kenti tahayyülünü ve temsilin mekânında bu tahayyülün mağdurlarının hayatta kalma direniş ve mücadelelerini görüyoruz.

\section{Ekümenopolis'in Pratikleri}

Günümüz için mekânsal pratik gündelik ve kentsel gerçeklikleri algılanan mekân içinde birbirleriyle birleştiriyor. Zaman kullanımına işaret eden gündelik 
gerçekliğin, çalışılan, dinlenilen, vakit geçirilen yerleri güzergâh ve ağlar ile birbirine bağlayan kentsel gerçeklik böylece mekânsal pratik bütününü oluşturuyor.

Ekümenopolis'te en yoğun sergilenen mekânsal pratik olarak inşa faaliyetlerini görüyoruz. Konutlar, alışveriş merkezleri, spor yapıları, yollar, köprüler, tüneller, geçitler filmde en çok işlenen sahne, bunları ortaya çıkaran pratikler yani inşaat faaliyetleri de en yoğun mekânsal pratik olarak karşımıza çıkıyor. Öyle ki, filmin başlangıç jeneriğinde, yapımda sorumluluk alan birçok teknik ve sanatsal emekçinin adları, bu yapıları fon alarak sunuluyor. Böylece, filmin esas başrolünü mekânların oynadığını ta baştan hissediyoruz.

Bu yoğun inşa faaliyetleri mekânda başka bir pratiğin de yayılmasına sebep oluyor. İmar süreçlerinin kentin çevre mekânlarına genişlemesi buraya yönelik ulaşım pratiklerinin de artması sonucunu doğuruyor. Bu tabii ki, tek yönlü bir determinizm değil; inşaat olduğu için, ulaşım altyapısı ve araçları çoğalmıyor, Haluk Gerçek'in animasyonla canlandırılmış ifadeleri (43:00) çoğu zaman altyapı ve ulaşım imkanlarına yönelik yatırımların müstakbel inşa pratiklerine nasıl zemin hazırladığını, bunları nasıl tetiklediğine işaret ediyor. Filmin üçüncü köprüye ayrılmış bölümü tam da mekânsal pratiklerin bu iki yönlü nedenselliğini işliyor. Örneğin Şükrü Aslan (39:45) İstanbul'da köprülerin ve bunlara bağlı çevre yollarının zemin hazırladığı yerleşmeleri İstanbul örneğinde semt semt belirtiyor.

Gerçek ve Aslan'ın filmdeki bu ifadeleri bir başka açıdan da tartışmamız adına önemli. Kendilerinden mülakat tekniği kullanılarak edinilen bilgiler, onların anlatımına eşlik eden grafik, harita ve animasyonlarla görselleştiriliyor. Böylece belgesel film sadece kameranın kaydedebildiği görsellikle yetinmeyerek, kamera ile kayıt altına alınan bilgileri başka teknikleri kullanarak görselleştirerek, anlatıma görsel bir katman daha eklemiş oluyor (Fotoğraf 1).

\section{Fotoğraf 1: Anlatının görselleştirilmesi; animasyon}

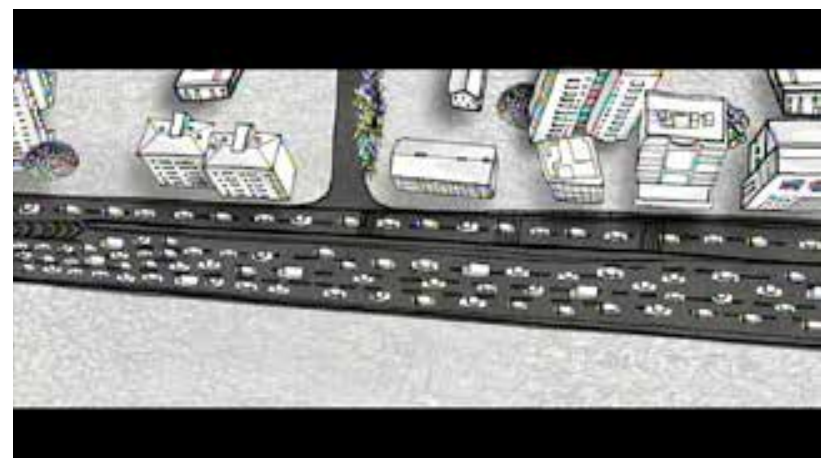

Bu hâkim inşa pratiği daha önceden kullanılmayan arazilerden ziyade insanların hâlihazırda kullandığı, bir yaşam kurduğu yerlerde gerçekleştiği için, 
yıkım faaliyetleri inşaatları önceleyen zaruri bir pratik olarak beliriyor. Filmin başlarında dünyanın farklı köşelerinde Çin'de, Pakistan'da, Portekiz'de ve tabii ki İstanbul'da kaydedilen yıkım görüntüleri tüm dünyada yaygın mekânsal pratik olarak karşımıza çıkıyor (14:46). Bu yıkımlara sadece iş makinelerinin tanıklık etmediğini, illa ki kolluk kuvvetleri ve onlara direnmeye çalışan mekânın eski sakinleri de söz konusu karelerde eksik olmadığını biliyoruz. Inşa pratiği, direniş ve çatışma pratiklerini de zorunlu kılıyor. Her mahallede kolluk kuvvetleriyle yaşanan çatışmalar ne yazık ki insanları evlerinden eden yeniden inşa faaliyetlerine engel olmaya yetmiyor (Fotoğraf 2).

Fotoğraf 2: Kolluk kuvvetlerinin nezaretinde yıkım

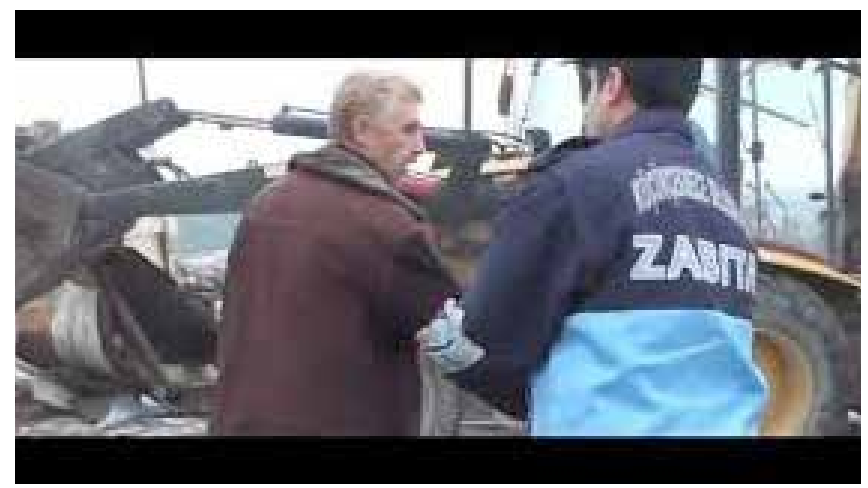

Zamanla her mahallenin kendi kendine, kendisi için verdiği mücadele yayılıyor. Örneğin Ayazma için farklı mahallelerde dayanışma çadırları kuruluyor (47:30). Belki de hiçbir siyasi mücadele yürütmemiş mahalleliler, canlı yayın programlarında dertlerini dillendiriyorlar (48:00), basın açıklamaları düzenliyorlar, yetkililerle görüşmeler yapıyorlar (50:00). Sonrasında da tüm kent hakkı mücadeleleri birleşip, büyük bir miting yapıyor (1:23:30) (Fotoğraf 3).

Fotoğraf 3: Kolektifleşip, yayılan direniş mücadeleleri

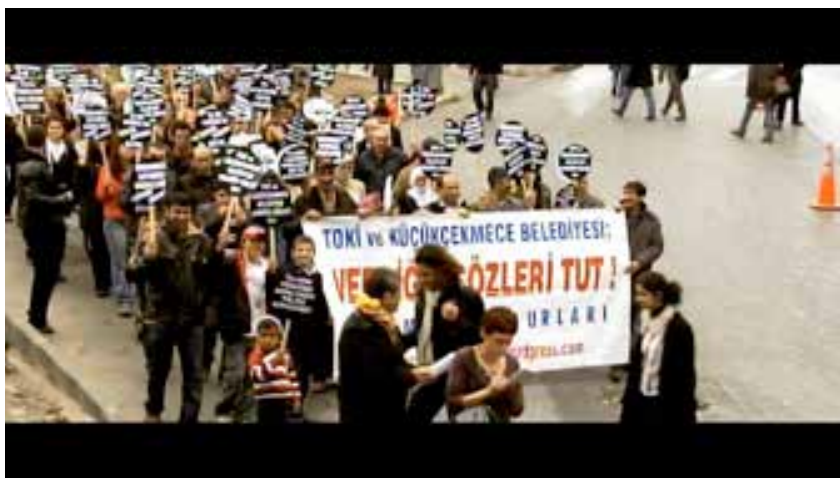


Tüm bu mekânsal siyasi pratikler aslında retrospektif olarak Gezi Olayları'nın habercisi olarak düşünülebilir. Sadece İstanbul'da değil, tüm Türkiye'de mekânın siyasal ve ekonomik elitler tarafından sömürülmesine dair isyan bir anda tüm ülkeyi etkisine almış ve eşi benzeri görülmemiş bir toplumsal eylemliliğin fitilini ateşlemişti. Ekümenopolis'te aktarılan bu mekânsal pratikler işte Gezi İsyanı'na giden yolun kaldırım taşlarıydı. Dahası isyanın nasıl gelişeceğine dair ipuçları vermekle kalmadı Ekümenopolis, karşı çıkılan, isyan edilen siyasi aklı, Lefebvre'in terimleri ile karşı çıkılan Mekânın Temsili'ne dair de önemli bir kaynak oldu.

\section{Ekümenopolis'in Temsili}

Yukarıda zikrettiğimiz tüm bu inşaat faaliyetleri ve bunlara karşı verilen mücadeleler mekânsal pratikler olarak mekândaki değişime işaret etse de, Lefevbre bunun mekânın üretimini tarif etmeye yetmeyeceğini iddia eder. Keza mekânın üretimi "tek başına herhangi bir 'gayrimenkulün', bir sarayın, bir anıtın inşası"ndan ibaret olamaz. Mekânsal üretim için bu inşanın "mekânsal bir bağlama dahil olan bir proje ve bir doku olarak tasarlanmış yapım, yani mimari yoluyla" yani "sembolik ya da imgesel olanın içinde kaybolmayan 'temsiller'in" bir parçası olması gerekir (Lefebvre 2014: 71).

Gayrimenkul Ortaklıkları Derneği Kurucu Başkanı Haluk Sur, Ekümenopolis'in başat temsilini filmin başında İstanbul'un bir dünya kenti olarak gördügünü söyleyerek (11:35) net bir şekilde ortaya koyuyor. Tarihi birikimin üzerinde modern bir gelecek IMAR ediyor olmakta olduklarını ve İstanbul'u dünyanın finans merkeze yapmaya dönük yatırımlara devam ettiklerini ifade eden, dönemin Başbakanı da (11:40) bu temsilin siyaseten de ne derece benimsendiğini gösteriyordu. Başbakan İstanbul'a biçilen bu misyonun ekonomiyle sınırlanmadığını, bir yıllık Avrupa Kültür Başkenti olma payesinin, İstanbul'un daimi kültürel merkez olma ayrıcalığının küçük bir çehresi olduğunu da ifade ediyor (13:30).

Bu temsilin Türkiye'ye, İstanbul'a özgü olmadığı, küreselleşmek isteyen tüm varlıklı kentlerin, mekânın böylesi bir temsilini tecrübe ettiklerini Yves Cananne'nın sözlerinden anlıyoruz (13:50). Dahası, Mücella Yapıcı, İstanbul'un bu temsilinin sadece gayrimenkul ortaklıklarının ya da hükümetin değil, Dünya Bankası gibi uluslararası örgütlerin de eseri olduğunu savunuyor (12:10). Bu temsile göre kentler hizmet sektörünün ve tüketimin yoğunlaştığı mekânlar olmak durumundadır. Üçüncü dünya kentlerinde bu süreç çok daha kuralsız ve vahşi işleyebilir. Nitekim Yapıcı (31:45), gelişmiş ülke yatırımcılarının hukuki ve demokratik sebeplerden kendi ülkelerinden yapamadıklarını Türkiye gibi ülkelerde hayata geçirdiğini vurgular. Central Parc'a yapılmayan otel, İstanbul'da bir parkın ortasında kendine rahatça yer bulabilir (32:20). Mustafa Sönmez mekânın temsilinin uluslararası kökenin ötesinde bölgesel de bir iddiası olduğunu ve İstanbul'dan Balkanlar, Ortadoğu ve Kafkaslar'a uzanan bir bölgenin yönetilmek istendiğini iddia eder (13:00) (Fotoğraf 4-5). 
Fotoğraf 4-5: Mekânın temsilinin temsili - Mustafa Sönmez ve Mücella Yapıcı
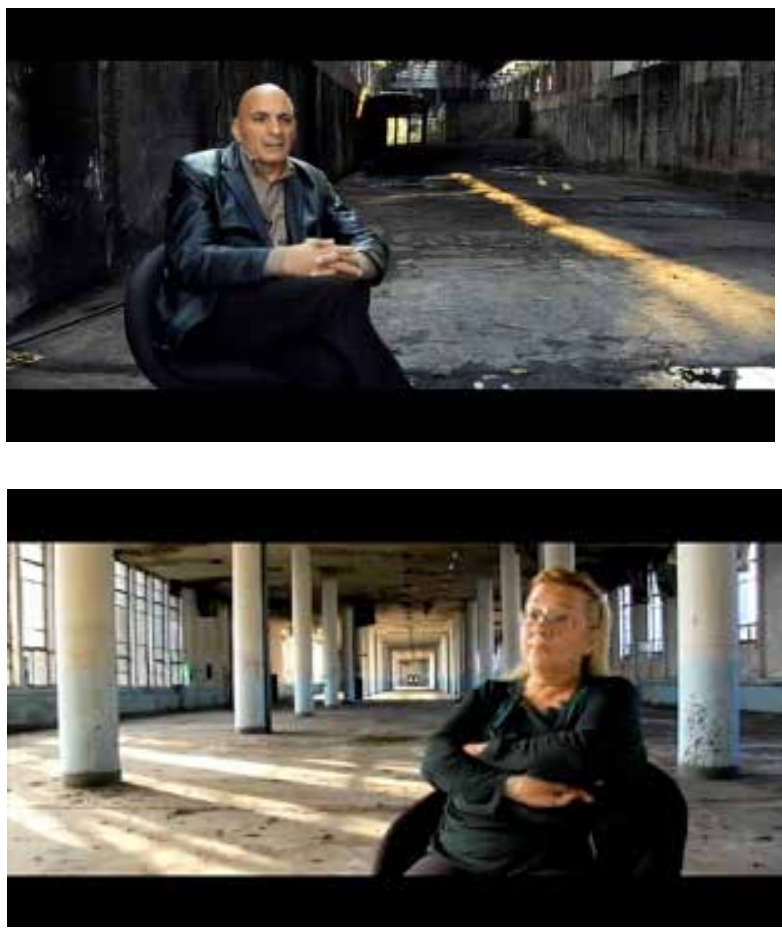

Filmde görüşlerine yer verilen bu uzmanların ifadeleri aslında mekânın temsilinde Türkiye için bir kırıma olduğunu düşündürüyor çünkü Lefebvre mekânın temsilini özellikle teknokratlar ve siyasetçilere atfediyordu. Oysa filmde izlediğimiz uzman görüşleri geçerli tasarıma çok eleştirel bakarak, mekânın temsilinden ayrılıyorlar. Fakat bu ayrılık daha sonraki kısımda ele alacağımız temsilin mekânına da sokulamaz çünkü söz konusu olan yaşanan bir mekândan ziyade, daha farklı şekilde tahayyül edilen bir mekân fikridir. Bu anlamda mekânın temsilinin eleştirel bir temsiline tanık oluyoruz, dolayısıyla da ancak mekânın temsilinin temsilinden bahsetmemiz gerekebilir.

Belgeselde yer alan mekânın temsilinin temsilini dillendiren uzmanların (Şükrü Aslan, Yves Canenne, Mücella Yapıcı, Mustafa Sönmez, Cihan Uzunçarşıı Baysal, Hatice Kurtuluş gibi) filmdeki çekimleri de görsel bir anlam taşır. Uzmanlar, geniş açılı objektifle çerçevelenmiş, ön planda göğüs ya da bel ölçekte konumlandırımış ve alan derinliğinden yararlanılarak arka planında ise kentsel dönüşüm yıkıntıları, TOKi konutları ya da metruk haldeki binalara yer verilmiştir. Filmin kentsel dönüşüm mağduru tanıkları ise eleştirel bakışın çözümlediği yaşayan mekânlarda gündelik pratikleri ile yer alırlar: kentsel dönüşüm yıkıntıları, zorla gönderildikleri yeni TOKi konutları, kolektif eylemin mekânı olarak sokaklar 
gibi. Uzmanlarının arka planında yer alan mekânların temsili, tanıkların gündelik pratiklerini kapsayan temsili mekânlara dönüşür (Fotoğraf 6-7).

Fotoğraf 6-7: Uzmanın mekânın temsili ile doğrudan bu kentsel dönüşümü yaşayanların gündelik pratiklerini kapsayan temsili mekânlar
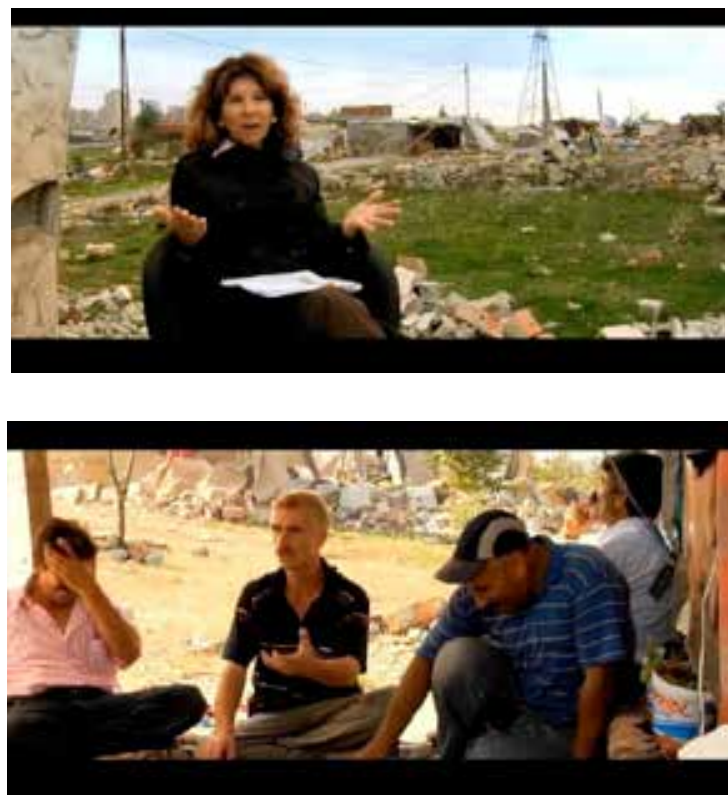

İstanbul'da gözlenen (ve uzmanlarca eleştirilen) bu mekân temsili sadece kentin belli bir işlevinin öne çıkarmaktan ibaret değil. Bu aslında başlı başına bir kent, daha doğrusu kentsel yaşam tahayyülü, temsili ifade ediyor. Sadece mekândan ibaret değil, bir yaşamın temsilini bu sürecin önemli aktörlerinden biri ve bu mekân temsilinin en ikonik faili olan Ali Ağaoğlu'nun Ayazma'da öngördüğü yaşam tarifinde buluyoruz (20:00): \%87'si (muhtemelen büyük kısmı golf sahasından oluşan) yeşil alan, yüksek katlarda bahçe, havuzlu, güzel, daireler sunan siteler. Yaşamdan anlaşılan lüks yaşam; temel barınma ve yaşam ihtiyaçları bu tanımda yer bulmuyor çünkü temel intiyaçların ya hâlihazırda sunulduğu düşünülüyor ya da bundan mahrum olanlar için yapılacak pek de bir şey olmadığı ima ediliyor. Nitekim Ağaoğlu'na göre Türkiye hala bir fırsatlar ülkesi; yeterince çalışan, azmeden başarıı olabiliyor (12:45). Ağaoğlu vermeden almanın sadece Allah'a mahsus olduğunu söylerken de, bu yeteri kadar çaba sarf etmediklerini ima ettiği kitlelere yapılacak bir şey olmadığını itiraf ediyor. Bu da kamusal kaynakların tarif ettiği bir yaşam temsiline aktaracak bir devletin de tarifi oluyor (24:00). Tüm bu ifade ve tarifleri Ağaoğlu'nun alaycı hal ve tavırları ile izlemek de, yapılan sosyolojinin duygusal boyutunu destekler bir örnek olarak zikredilmeyi hak ediyor (Fotoğraf 8). 


\section{Fotoğraf 8: Ali Ağaoğlu}

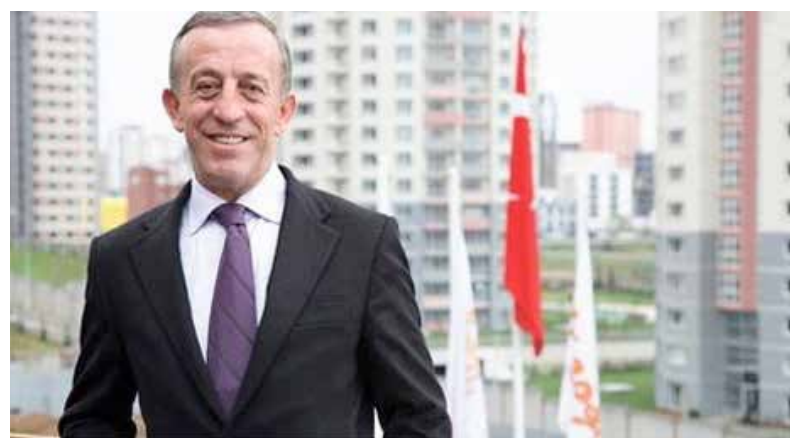

Ağaoğlu'nun ifadelerinde teşhis ettiğimiz bu mekân temsilinin bir fantezi olmadığını ve mevcut anayasanın ruhunun da buna mahal verdiğini Cihan Uzunçarşılı Baysal'ın sözlerinden hissediyoruz (26:00). Nitekim Baysal barınma hakkının anayasada tanımlanmadığını, bunun ancak konut, dokunulmazlık, özel hayat gibi haklardan çıkarsama yoluyla tarif edilebildiğini dile getiriyor. Barınma hakkının ancak dolaylı çıkarsamalarla tarif edilebilmesi, farklı mekân temsillerini de mümkün kılan bir imkân yaratıyor. Öyle ki, tam da barınma sorununu çözmek için yapılandırıldığı iddia edilen Toplu Konut İdaresi Mücella Yapıcı'ya göre (57:00) son dönemde aşırı yetkilerle donatııp, "müthiş bir imparatorluk haline geliyor." Sosyal konuttan ziyade lüks konutlara yönelmiş, kamu yararından çok kentsel rantın yaratııp, paylaştııılmasında uzmanlaşmış bir kamu kurumundan bahseder hale gelmiş oluyoruz.

Mekânın sosyal/kamusal amaçlardan ziyade rant birikimine hizmet edecek şekilde temsil ediliyor olduğunu sadece TOKi'de rastlıyor değiliz. Oktay Ekinci (1:12:40) meclisteki siyasetçilerin uzmanların yaptığı planları kafalarına göre değiştirmelerine yönelik itirazı da aslında bu temsile dair işaretler taşıyor. Bilimin gerektirdikleri özel çıkarlarla çeliştiğinde birinciler feda edilebiliyor. Bu tercihin resmi olarak tescillenmesi de gerekmeyebiliyor. Örneğin Haluk Gerçek İstanbul'daki üçüncü köprü, boğaz karayolu tünel geçişi veya diğer karayolu tünelleri gibi çok önemli yatııımların İstanbul'un mevcut II Çevre Düzeni Planı'nda olmadığı halde süreçlerin işlediğini belirtirken aslında mekânın resminin yanı sıra fiili bir temsili olabildiğini de anlatmış oluyor (1:12:50). Uzmanlık tanımayan rant arayışı, gerektiğinde hukukun bile çevresinden dolaşabiliyor.

Bu uzmanlık, hukuk tanımamazlık şu andaki küresel intiraslar ve rant arayışı bakımından 1980 sonrasına ait olsa bile, bu anlayışın köklerinin çok eskilere gittiğini de akılda tutmalıyız. Ayazma sakini Kasım Aydın, her seçim döneminde altyapı hizmetlerinin nasıl peyderpey geldiğini anlatırken (22:30), bu hukuk ve bilim tanımaz mekân temsilinin seçim popülizm içinde eskiden beri araçsallaştırıldığını da belirtmiş oluyor. 
Ekümenopolis filmi mekânın Türkiye'deki hakim temsiline dair çok önemli ipuçları içeriyor. Barınma/konut hizmetlerinin artık kamu yararı için kurgulanan bir yatırım alanı olmaktan çıkıp, bir sermaye aktarım amacı olmasını, bu süreçten en çok yararlanan müteahhidin şahsiyetinde gözlüyoruz. Küresel bir finans ve kültür kenti olma intirasıyla kamufle edilen bu temsil, bilim ve hukukun gerektiğinde ikinci plana atımasını mümkün kılabiliyor. TOKi gibi devasa yetki ve kaynaklarla donatılmış bir kamu kurumu üzerinden kotarılan bu sürecin o mekânların eski sakinlerinin hayatlarına etkileri de bizi Ekümenopolis içindeki mekânın temsiline dair izlere getiriyor.

\section{Temsilin Ekümenepolis'i}

Siyasi iktidarın küresel kent olma yolunda giriştiği inşaat faaliyetlerinin sebep olduğu yıkım, yerinden edilme ve çatışma pratiklerine yukarıda değindik. Fakat bu gözden çıkarılan mekânların, orayı bir yaşam alanı olarak görenler için neler ifade ettiği, bu rant odaklı mekân temsiline hiç uymuyor. Nitekim bir yaşam alanının muktedirlerin, uzmanların, karar alıcıların dilediği, planladığı gibi şekillenmediğini biliyoruz. Bunun en manidar örneğini filmde (27:15) Tacettin Aydın'ın yüksek duvarlarla çevrili bir işyerinden nasıl çıktığını gösteren sahne ile görüyoruz. O duvarların, tellerin neye, ne kadar hizmet edebileceğini bilmek zor; bir mekânın kullanıcılarının yapılı ve planlı çevreyi hiç de beklenmedik şekillerde kullanabildiklerini bu sahnede görüyoruz.

Ayazma'daki yıkımın hemen ardından Kasım Aydın ve komşularının yıkım araçları gider gitmez başlarını sokacak bir yer oluşturma çabaları mekânın yıkımı ile inşasının nasıl birlikte ama zıt yönlerde gidebileceğini gösteriyor (18:00-19:50). Yıkım, anında, yıkılanın yeniden inşasını getiriyor çünkü yok edilmesine kalkışılan yaşamın kökenindeki sebepler durduğu sürece aynı yerde ve mümkün olabilen en yakın yerde o yaşamın tekrar belirmesi kaçınılmaz. Özellikle enkazın içinde, açık alanda soba kurmaya çalışan çocukları gösteren sahne (18:17), temsilin mekânı nasıl tekrar, tekrar kurabildiğini ve kurabileceğini ortaya koyuyor. Fakat bu yeniden yeniden kurulan yaşam aynı zamanda bir yoksulluk sarmalının da içinden çıkılmaz durumunu gösterir. Tacettin Acar bu yıkımlar ve yeniden yaşam kurma zorluklarının çocuklarının eğitimine nasıl engel olduğunu anlatırken (27:00), yıkımın, yok edilmeye çalışan yaşamı nasıl kaçınılmaz kıldığını açıklamış oluyor (Fotoğraf 9). Bu anlatılara eşlik eden sahneler de Bediz Yılmaz'ın (2008) "müebbet yoksulluk" olarak tarif ettiği yoksulluk sarmalının en gerçekçi belgeleri olarak filmdeki yerini alıyor. 


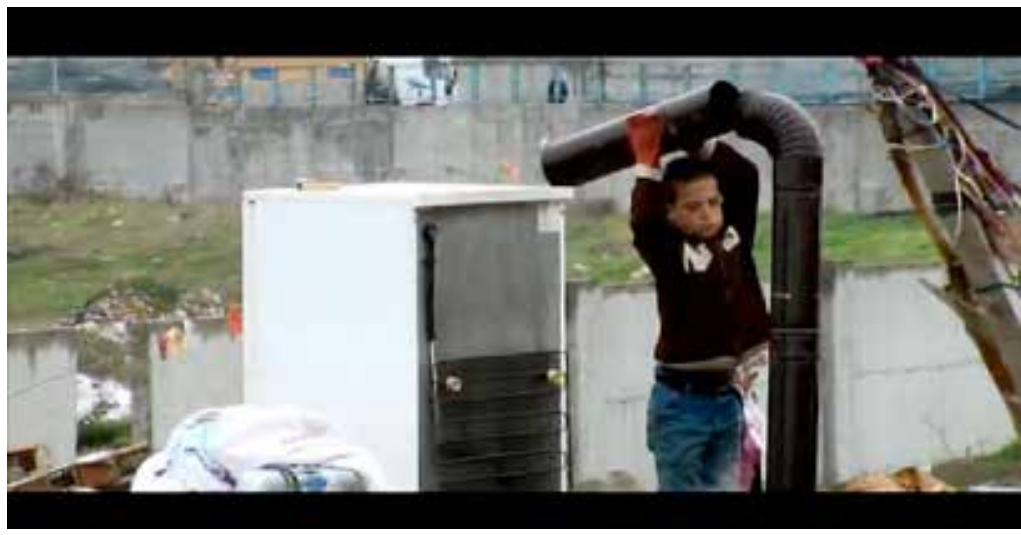

Böylesi bir yoksulluk sarmalına girişin sebebi, Hatice Kurtuluş'a göre gecekonduyu sosyal bir sorun değil, bir bina sorunu olarak görmekte yatıyor (56:00). Derme çatma, güvenli ve yasal olmayan yerlerde yaşamak durumunda olmanın sadece fiziki koşulları öne çıkarılıp, bu fiziki koşulların değiştirilmesinin sorunu çözdüğü düşünülüyor. Oysa Mekânın Temsilince gayri-çağdaş, sağlıksız ve çirkin olarak addedilen yaşam alanları, orada yaşayanların gözünde bambaşka bir anlam taşıyor. Mesela Tozkoparan Mahallesi Muhtarı Ömer Kiriş'e kulak verelim:

“Bizim 50 yıldan beri yaşadığımız, çocukluğumuzu, evliliğimizi, aşklarımızı sevgimizi, dertlerimizi, hüzünlerimizi, cenazelerimizi paylaştığımız mahallemizin dokusuna dokunamazlar, dokunmamalılar. Ben gökdelenlerde yaşamayı mutluluk olarak saymıyorum. Bizim parayla pulla işimiz yok. Bizim barınma haklarımızı kesinlikle yok etmelerine karşıyız, yok edilmesine karşıyız ve bunun karşısında da sonuna kadar duracağız." (1:20:00-1:20:25).

Dahası çağdaş konut adı altında arz edilen yaşam alanlarının iddia edildiği kadar sağlıklı ve güvenli olduğuna dair da büyük şüpheler var:

"Buraya dediler ki sizi götüreceğiz, doğal yaşamınız, sağlık yönünden sizi güzel bir yere götürüyoruz. Ondan sonra koydular bizi buraya, Ayazma yine iyiydi ablacığım, daha iyiydi buraya göre. Altyapımı yapmış, benim balkon burada altyapım burada. Kokudan inan ki, kapımı açamıyorum" (1:01:10).

Görüldüğü gibi vaat edilen fiziki koşulların gerçeği yansıtmadığı kısa zamanda anlaşılıyor. Fakat daha vahim olan, sorunun görmezden gelinen sosyal boyutu, bu şehrin uzak köşelerine göç etmek zorunda bırakılanların maruz kaldığı sosyo-ekonomik sorunlar. Cazip fiyat ve ödeme kolaylığı kisvesi altında sunulan TOKi konutlarının borcunu ödemek birçok hak sahibi için söylendiği kadar kolay değil. Filmde Tacettin Acar da (52:00), Levent Umaç da (1:06:50) taksitleri 
ödemede yaşadıkları sorunlara dem vuruyorlar. Bu taksitleri karşılayacakları ekonomik güçleri yok çünkü mesela ayakkabıcılık gibi gerçek işlerini yapamıyorlar ya da mesafenin uzaklığından dolayı yaptıkları işten para kazanamaz hale geliyorlar (Cafer Gitmez, 1:08:15). Uzun zaman kurulan yaşam biçimlerinin, ekonomik çözümlerin Taşoluk gibi tamamen yeni ve yabancı bir mekânda devam ettirilmesi mümkün olmayacağı için buraların sakinlerinde büyük bir bilinmezlik hâkim (Levent Umaç, 1:07:40): "Affedersin" diyor Cafer Gitmez "evin duvarlarını mı yiyecez, abi?".

Bu yeni yerleşmeler ekonomik sorunları ağırlaştırmakla da kalmıyor, yeni çok ciddi sorunlara gebe gibi de görünüyor. Nitekim Hatice Kurtuluş (1:04:00) da, Şükrü Arslan da (1:04:45) yoksulların kentin dışına sürülmesi kentte bir sınıfsal yarılma yarattığını düşünüyor. Bu da Arslan'ın deyişi ile kentliliğin inkârına yani çeşitliliğin yok edilmesine tekabül ediyor.

Filmin sonlarına doğru Ayazma sakinlerinin eski mahallelerinde inşa edilen Olimpiyat Stadı'nda gerçekleşen U2 konserini uzaktan izlemeleri bu ayrışmayı çok net sergileyen bir karedir (Fotoğraf 10). Aslında kendilerine ait bir mekânda yapılan yeni yapı ve oluşan sosyo-kültürel yeni yaşamın tamamen dışında ve uzağında kalmak zorunda olan yoksullar (1:16:30)... Bunun sonucunda zenginler ve yoksulların birbirlerinden bu kadar ayrıştırılması, bu iki grubun birbirlerini başka bir cins olarak görme sonucunu doğurabilir diyor Kurtuluş (1:04:15). Bu da Batılı ülkelerde bile artık görülebilen toplumsal çatışma ve şiddete yol açabiliyor.

\section{Fotoğraf 10: U2 konserinin yerinden edilen izleyicileri}

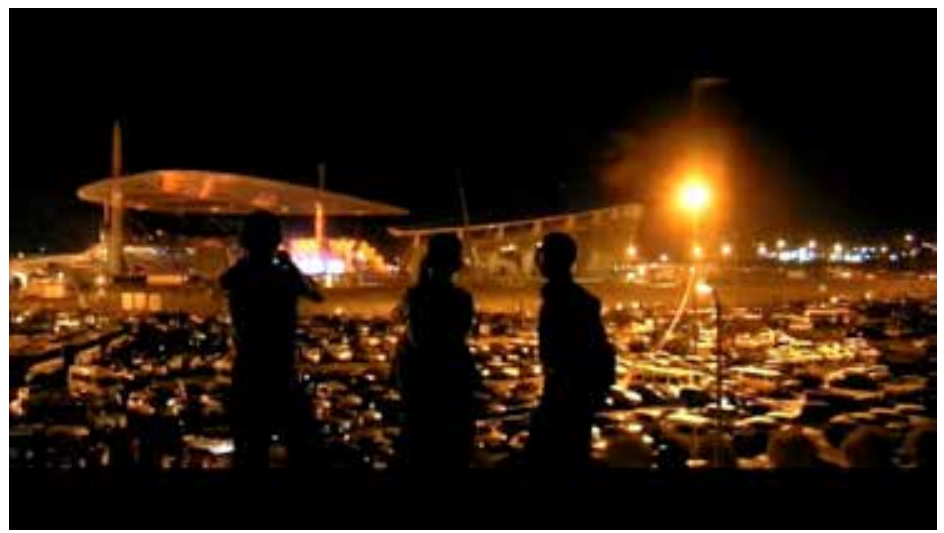

Ekümenopolis'te izlediğimiz temsilin mekânının bir önceki bölümde çerçevesi çizilen mekânın temsilinden tamamen farklı olduğu anlaşılıyor. Küresel kent ihtirası ile meşrulaştırılan rant odaklı mekân kullanımının sağlıksız, huzursuz, ilkel diye nitelendirdiği mekânlar, oralarda yaşayanlar için bir mahalle sıcaklığını temsil ederken, tam zıt sıfatlarla nitelenen yeni sosyal konutlar çok 
daha içinden çıkılmaz sosyo-ekonomik sorunları tetikliyor. Bu anlamda mekânın temsili ile temsilin mekânı hem yıkımın hem de inşanın konusu olan mekânlarda birbirlerinden mutlak bir şekilde ayrı düşüyorlar.

\section{Sonuç}

Gill Scott-Heron 1970 tarihli Small Talk at 125th and Lenox adlı albümünün açılışını "Devrim Televizyonlardan Yayınlanmayacak [The Revolution Will Not Be Televised]" diyerek yapıyordu. Aradan geçen neredeyse yarım asır ScottHeron'u hem haklı, hem de haksız çıkaracak gibi gözüküyor. Çünkü evet devrimler televizyonlardan yayınlamıyor, hatta televizyonların aktarmaya cesaret edebildikleri haberlerin kapsamı gitgide daralıyor. Fakat öte yandan, hayır artık devrimler belki televizyonda değil ama başka ekranlarda hayal edilemeyecek ayrıntıda ve sıcaklıkta yayınlanabiliyor. Küçücük bir telefon kamerası devasa bir canlı yayın aracına dönüşerek, olup biteni an be an ya da sonrasında gezegenin en uzak köşesindeki yabancılara kadar ulaştırabiliyor.

Görüntünün bu kadar kolay elde edilebilir ve paylaşılabilir olmasının sayesinde sosyal bilimciler de, görsel verileri çözümlemelerinde gitgide daha fazla kullanıyor. Bu görsellik, araştırma bulgularının renksiz-kokusuz delil olmanın ötesinde, duygularıyla da tartışmaya katılabilmelerini sağlıyor. Bu duygulardan azade olmayan analizlerin en popüler örnekleri belgeseller sayılabilir. Belgesel sinema, sosyal olaylar ve sosyal tipler üzerine yapılandığı için duygular sosyolojisini doğal olarak anlatısında barındırıyor. Böylece olan biteni sadece uzmanların kuru dilinden değil, sosyal aktör olarak konunun tanık ya da faillerinin dilinden, duygularından anlayabilmemizi sağlıyor. Baker'den hareketle belgesel, düşünürken aynı zamanda hissedilmeye de kapı açmamızı sağlıyor.

Bu yazının inceleme odağı olan Ekümenopolis de en güncel siyasi konulardan birini, uzmanları uzmanlık diline hapsetmeden, konunun tüm muhataplarını savcı ya da avukatlık konumuna indirgemeden ağırlayarak ele alıyor. Dahası, böylesine bir kapsam filmin gayet kuramsal çerçeve içinde ele alınabilmesini bile mümkün kılıyor. Nitekim bu metin çerçevesinde Lefebvre'in mekânsal pratikler, mekânın temsil ve temsilin mekânından oluşan triyalektik yaklaşımını filme uyarlamaya çalıştık. Inşaat, ulaşım ve yerinden edilmenin öne çıktığı pratiklerin arka planında İstanbul'u bir küresel finans merkezi olarak kurgulayan mekân temsilini buluyoruz. Fakat kamera bu pratik ve temsilin mağdur muhataplarına döndüğünde bambaşka bir temsil mekânı görülüyor. Bu anlamda, Ekümenopolis İstanbul'daki pratik-mekân-temsil ilişkilerinin görselleştirilmiş bir izleği olarak, bu metin ve benzerlerinin yıllardır, cilt cilt ifade etmeye çalıştıklarını 90 dakikaya sığdırmış görünüyor. 


\section{Kaynakça}

AKŞEKER Semih ve vd. (2013), Milyonluk Manzara, İstanbul, İletişim Yayınları. AYTAÇ Senem vd. (2012), "Neoliberal Saldırıya Bütünlüklü Bakış Ekümenopolis", Altyazı, Sayı: 117, ss. 32-34.

AZEM İmre (2011), Ekümenopolis: Ucu Olmayan Şehir (DVD), İstanbul, Kibrit Film.

BAKER Ulus (2002), Video Üstüne., http://www.korotonomedya.net/kor/index. php?id=21,147,0,0,1,0, [15.04.2015].

BAKER Ulus (2010), Kanaatlerden Imajlara Duygular Sosyolojisine Doğru, Çev. Harun Abuşoğlu, İstanbul, Birikim.

BANKS Marcus (2010), Visual Methods in Social Research, Los Angeles, Sage.

BAYRAKTAR Ulaş ve ERKILIÇ Hakan (2014), “Direnişin Gölgemsi Ruh Hali: Gezi Filmleri", Sinecine, Sayl: 5(2), ss. 121-128.

BRENER Neil, vd. (der.) (2014), Kar lç̧in Değil Halk için, İstanbul, Sel.

BOURDIUE Pierre (2010), Düşünsel Bir Antropoloji lç̧in Cevaplar, Çev. Nazlı Ökten, İstanbul, İletişim Yayınları.

COSTES Laurance (2010), “Le Droit À La Ville de Henri Lefebvre: Quel Héritage Politique Et Scientifique?", Espaces et sociétés, Sayı: 1 (140-141), ss. 177-191.

DOXIADIS Constantinos A. (1968), Ecumenopolis: Tomorrow's City, http:// www.doxiadis.org/Downloads/ecumenopolis \%20tommorow\%27s\%20city.pdf, [15.04.2015].

GÜLHAN Sinan T. (2013), “Özgürlüğün Coğrafyası: Mekânsallığın Triyalektik Praksisi ve Bütünsellik Arayışına Dair Bir Tahlil", Mülkiye Dergisi, Sayı: 37 (1), ss. 31-69.

HALL Stuart (der.) (1994), “ideolojinin Yeniden Keşfi: Medya Çalışmalarında Baskı Altında Tutulanın Geri Dönüşü", Medya, Iktidar, Ideoloji, Çev. Mehmet Küçük. Ankara, Ark Yayınevi.

HARPER Douglas (1988), "Visual Sociology: Expanding Sociological Vision" The American Sociologist. Spring, s. 54-70.

HARVEY David (2008), "The Right to the City," New Left Review, Sayı: 53, EylülEkim, ss. 23-40.

KARS KAYNAR Ayşegül (2015), Sermayenin Coğrafyası, İstanbul, Notabene. KOCA Aysun vd. (der.) (2014), Kentleri Savunmak, İstanbul, Notabene.

LA ROCCA F. (2012), "Görsel Sosyoloji", Çev. Ezgi Bakçay, IFSAK Fotoğraf ve Sinema Dergisi, Sayı: 146, ss. 68-71. 
LEFEBVRE Henri (2011 [1972]), "Kent Hakkı", Çev. G. Aksümer ve J. Strutz, Eğitim Bilim Toplum Dergisi, Sayı: 9 (36), ss. 140-152.

LEFEBVRE Henri (2013), Kentsel Devrim, İstanbul, Sel Yay.

LEFEBVRE Henri (2014), Mekânın Üretimi, İstanbul, Sel Yay.

OCAK Ersan (2008), "Sosyal bilimler, belgesel sinema, video: Ulus Baker izleklerinde yürümek", Toplum ve Bilim, Sayı.111, ss.231-240.

ÖZBAY Cenk ve CANDAN Ayfer Bartu (2014), Yeni Isstanbul Çalışmaları, İstanbul, Metis Yay.

PAUWELS Luc (2010), "Visual Sociology Refremed", Sociological Methods \& Research, Sayı: 38 (4), ss. 545-581, doi: 10.117710019124110366233.

SCHMID Christian (2014), "Henri Lefebvre, Kent Hakkı ve Yeni Metropol Yeni Akımı", içinde Brenner, Marcuse ve Mayer (ed.), Kar için Değil, Halk Için, Sel Yay., ss. 72-99.

SCMITH, Neil ve WILLIAMS Peter (2015), Kentin Mutenalaştırılması, İstanbul, Yordam Kitap.

SUSAM Asuman (2015), Toplumsal Bellek ve Belgesel Sinema, İstanbul, Ayrıntı. TÜRKÜN Asuman (der.) (2014), Mülk Mahal Insan, Istanbul, İstanbul Bilgi Üniversitesi Yayınları.

YILMAZ Bediz (2008), “Türkiye'de Sınıf-altı: Nöbetleşe Yoksulluktan Müebbet Yoksulluğa", Toplum ve Bilim, Sayı.113, ss. 127-145. 